\title{
Posterotestes unelen gen. et sp. n. (Digenea: Apocreadiidae) from Percichthys trucha (Osteichthyes: Percichthyidae) in Patagonia, Argentina
}

\author{
Margarita Ostrowski de Núñez ${ }^{1}$, Norma Brugni ${ }^{2}$ and Verónica R. Flores ${ }^{2}$ \\ ${ }^{1}$ Departamento de Ciencias Biológicas, Universidad de Buenos Aires, Ciudad Universitaria, Pabellón II, (1428) Buenos Aires, \\ Argentina; \\ ${ }^{2}$ Centro Regional Universitario Bariloche, Universidad Nacional del Comahue, Avda. Quintral 1250, (8400) Bariloche, \\ Argentina
}

Key words: Digenea, Apocreadiidae, Posterotestes unelen, Percichthys trucha, Patagonia

\begin{abstract}
Posterotestes gen. n. (Digenea: Apocreadiidae, Apocreadiinae) is proposed for specimens with the following features: spiny body, posterior position of gonads, extension of vitelline follicles up to level of intestinal bifurcation and absent at posttesticular space, long oesophagus and extension of caeca up to anterior testis. Posterotestes unelen sp. $\mathrm{n}$. is described from the intestine of the native fish, Percichthys trucha (Cuvier et Valenciennes) (Osteichthyes: Percichthyidae) from Patagonian Andean lakes.
\end{abstract}

The freshwater and estuarine species of the family Percichthyidae are distributed in Australia and South America (Nelson 1994). Percichthys trucha (Cuvier et Valenciennes) is a freshwater species of the austral zone of Chile and Argentina (Arratia 1982) and one of the most abundant native species in Andean Argentinean lakes. It is mainly a benthic feeder (Macchi et al. 1999) and can attain $50 \mathrm{~cm}$ in body length.

The digenean parasites of freshwater fishes in the Andean Patagonian region have been extensively studied in recent years (Ortubay et al. 1994, Ostrowski de Núñez et al. 1999, 2000, Viozzi et al. 1999, Shimazu et al. 2000). Intestinal digeneans recorded from P. trucha are Acanthostomoides apophalliformis Szidat, 1956, Genarches patagonicus Szidat, 1956, Austrocreadium papilliferum (Szidat, 1956), Allocreadium patagonicum Shimazu, Urawa et Coria, 2000 and Polylekithum percai Ostrowski de Núñez, Brugni et Viozzi, 2000 (Szidat 1956, Torres et al. 1992, Ostrowski de Núñez et al. 1999, 2000, Shimazu et al. 2000).

In this paper a new genus is proposed, belonging to the subfamily Apocreadiinae (which is included within the family Apocreadiidae) for specimens recovered from the intestine of $P$. trucha from Patagonian Andean lakes.

\section{MATERIALS AND METHODS}

The surveyed lakes $\left(38^{\circ} 55^{\prime} \mathrm{S}\right.$ to $\left.42^{\circ} 36^{\prime} \mathrm{S}\right)$ are deep, of glacial origin and with a circulation period in winter and a stratification period in summer (Table 1). They belong to different basins and drain to the Pacific Ocean (Epuyén, Rivadavia) or to the Atlantic Ocean (Aluminé, Traful, Escondido and Moreno).
Samples of $P$. trucha were taken bimonthly (1996-1998) from Lake Escondido, seasonally (1999-2001) from Lake Moreno and only one sample was taken in summer from Lakes Aluminé, Traful, Rivadavia and Epuyén. The fish were captured with gill nets, killed, transported to the laboratory, maintained at $7^{\circ} \mathrm{C}$ and dissected during the following two days.

Parasites were fixed in hot 5\% formalin, stained with hydrochloric carmine and mounted in Canada balsam. Some details were observed in live specimens. Also, some specimens were embedded in paraffin wax, cut at $7 \mu \mathrm{m}$, stained with haematoxylin and eosin, and mounted in Canada balsam. Measurements, based on 20 ovigerous specimens, are given in micrometres as the range followed by the mean in parentheses. Figures were drawn with the aid of a camera lucida and details added free-hand. The term forebody refers to the distance between anterior extremity of body and anterior border of ventral sucker while hindbody to the distance be-tween posterior border of ventral sucker and posterior extrem-ity.

Prevalence, mean intensity and abundance are used following Bush et al. (1997).

\section{RESULTS}

A total of 529 P. trucha were dissected. The prevalence, mean intensity and abundance of $P$. unelen for each lake are shown in Table 1.

\section{Posterotestes gen. n.}

Diagnosis. Tegument spinous. Dispersed eye-spot pigment generally present near pharynx and/or oesophagus. Oral sucker simple, opening subterminally. Ventral sucker simple, in anterior half of body.

Address for correspondence: V.R. Flores, Laboratorio de Parasitología, Centro Regional Universitario Bariloche, Universidad Nacional del Comahue, Avda. Quintral 1250, (8400) San Carlos de Bariloche, Argentina. Phone: ++54 2944 423374; Fax: ++54 2944 422111 ; E-mail: vflores@crub.uncoma.edu.ar 
Prepharynx present. Pharynx simple. Oesophagus long. Caeca extending to anterior testis. Two testes in tandem or slightly oblique at posterior extremity of body. Seminal vesicle naked, postero-dorsal to ventral sucker. Prostate cells free in parenchyma. Pars prostatica distinct. Ejaculatory duct unites with uterus to form hermaphroditic duct. Hermaphroditic duct opens through genital pore. Genital pore median and anterior to ventral sucker. Ovary entire, anterior to testes. Laurer's canal and canalicular seminal receptacle present. Vitelline follicles extend anteriorly to level of intestinal bifurcation, and posteriorly to level of anterior border of posterior testis. Uterus extending between ovary and ventral sucker. Eggs operculate. Excretory vesicle tubular, reaching anterior testis. Excretory pore terminal. Type species: Posterotestes unelen sp. n.

Comments. Cribb and Bray (1999) recognised 13 valid genera in the Apocreadiinae. Six genera exhibit some special features, not present in Posterotestes, such as folded body margins (Choanodera Manter, 1940), cyclocoel (Trematobrien Dollfus, 1950), oral sucker with elongate processes (Dactylotrema Bravo-Hollis et Manter, 1957), ventral sucker with lamellar lips (Marsupioacetabulum Yamaguti, 1952), ventral sucker with bilobed flap (Myzotus Manter, 1940), and pharynx larger than ventral sucker (Neomegasolena Siddiqi et Cable, 1960). Four genera have the vitelline follicles restricted to the hindbody, extending posterior to the tes-tes (Homalometron Stafford, 1904, Microcreadium Simer, 1929, Procaudotestis Szidat, 1954, and Callohelmis Cribb et Bray, 1999). Posterotestes differs from Procaudotestis, the only other genus with the testes near posterior extremity, by the presence of tegumental spines, oesophagus longer than the pharynx, caeca extending only to anterior testis, ovary contiguous to anterior testis, uterus short with few eggs and not overlapping testes, vitelline follicles extending from intestinal bifurcation to anterior border of posterior testis (Szidat 1954, Bray et al. 1996). The remaining three genera, which have the vitelline follicles extending into the forebody, differ from Posterotestes as follows: Crassicutis Manter, 1936 by its smooth tegument and smaller body length; Neoapocreadium Siddiqi et Cable, 1960 by the position of gonads and the short oeso-phagus; and Pancreadium Manter, 1954 by the position of the genital pore and the deeply lobed ovary.

The combination of the following characters, presence of tegumental spines, long oesophagus, caeca terminating at the level of the anterior testis, gonads close to the posterior end of the body, and vitelline follicles extending close to the intestinal bifurcation but absent in the post-testicular space, distinguish the specimens stud-ied from all other genera in the subfamily. We consider these differences sufficient to erect a new genus.
Description $(n=20)$. Body elongate, 1,085-1,661 $(1,305) \times 211-413(310)$, width at level of ventral sucker 17-34 (24) \% of body length. Tegument with scale-like spines, 8-12 (10) at pharynx level, diminishing in size and number to 5-7 (6) at end of body. Oral sucker 95-187 (113) × 90-176 (127), oval to rounded, without lobes, subterminal. Prepharynx 31-101 (62), distinct, usually longer than pharynx. Pharynx 39-59 (46) $\times$ 42-78 (52), globular and muscular. Dispersed eye-spot pigment generally present near pharynx and/or oesophagus. Oesophagus 134-883 (237) long, sometimes slightly sinuous. Intestinal bifurcation slightly anterior to ventral sucker. Caeca terminate blindly close to anterior testis. Ventral sucker 90-160 (115) × 90-174 (121), similar to oral sucker, rounded, in anterior half of body. Sucker-ratio (ventral sucker/oral sucker) length: 1 : 0.83-1.25 (1.02); width 1 : 0.86-1.08 (0.95).

Testes two, entire, slightly oblique, situated 25-98 (52) from posterior end of body. Anterior testis 112$171(138) \times 109-196$ (147); posterior testis 115-196 (145) $\times$ 95-196 (148). Seminal vesicle elongate, reaching $2 / 3$ distance between ventral sucker and ovary. Prostatic gland-cells lie laterally to anterior part of seminal vesicle, ending in distinct pars prostatica. Hermaphro-ditic duct short, approximately 56 long. Genital pore median, 8.4-14 (11) anterior to ventral sucker.

Ovary 50-98 (74) × 59-120 (79), spherical, entire, sinistral (90\%), immediately anterior to testes. Canalicu-lar seminal receptacle small, blind, partially overlapping ovary. Ootype surrounded by Mehlis' gland anteriorly to ovary. Laurer's canal opens dorsally at level of ovary. Vitelline follicles $20-50(32) \times 17-48$ (30), extending 22-84 (40) anteriorly to ventral sucker and at level of intestinal bifurcation and to anterior border of posterior testis. Vitelline reservoir partially overlapping Mehlis' gland and ovary. Uterus between ovary and ventral sucker. One to 9 (4) yellow operculate eggs, 70-95 (82) × 34-53 (41).

Excretory vesicle tubular, extending to middle of anterior testis; excretory pore terminal. Lymphatic vessels not observed.

T y p e hos t: Percichthys trucha (Cuvier et Valenciennes, 1883) (Perciformes, Percichthyidae).

$\mathrm{S}$ i t e of infection: Posterior part of intestine.

T y p e 1 o c a 1 i t y : Lake Epuyén (42 $\left.11^{\prime} \mathrm{S}, 71^{\circ} 31^{\prime} \mathrm{W}\right)$, Province of Chubut, Argentina. Collection date: 4 February 2000.

Prevalence in type 1 ocality: 6.3\%. (Other localities: see Table 1.)

S p e c i m e n s d e p o s i t e d : Holotype No. $422 / 1$ and 2 paratypes No. 422/2-3 deposited in the Colección Nacional de Parasitología (MACN-Pa) in the Museo Argentino de Ciencias Naturales B. Rivadavia, Buenos Aires, Argentina; 

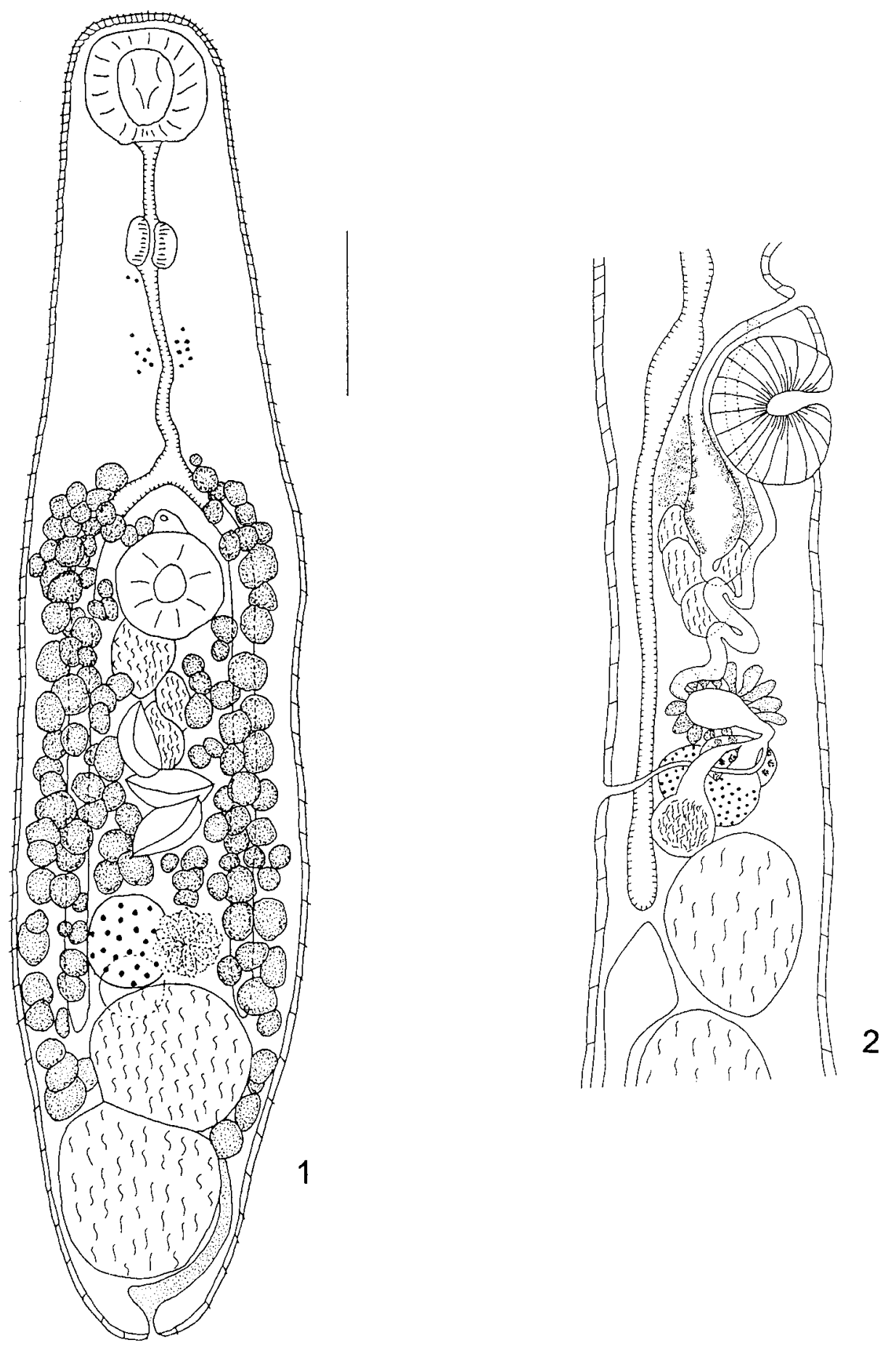

Figs. 1, 2. Posterotestes unelen sp. n. Fig. 1. Holotype, ventral view. Fig. 2. Terminal genitalia, reconstructed from serial histological sections. Scale bar (Fig. 1) $=100 \mu \mathrm{m}$.

3 paratypes No. 5101 in the Colección Helmintológica del Museo de La Plata, Museo de La Plata, Argentina; 12 paratypes Nos. 96/1-2, 98/1, 107/1, 142/1-3, 143/1-2, 144/1-3 and 2 sets of serial sections No. 165/1-2, deposited in the Colección Parasitológica de la Universidad Nacional del Comahue (Bariloche, Argentina); 2 paratypes
No. D-470 deposited in the Helminthological Collection, Institute of Parasitology, Academy of Sciences of the Czech Republic, České Budějovice.

E t y m o 1 o g y: The specific name 'unelen' ('unelen', in Mapuche language, 'the first') refers to the first species described of the new genus Posterotestes. 
Table 1. Percichthys trucha: geographical position of the lakes, number of fish sampled, host length (cm), and prevalence, mean intensity and mean abundance of Posterotestes unelen sp. $\mathrm{n}$.

\begin{tabular}{|l|c|c|c|c|c|c|c|}
\hline \multicolumn{1}{|c|}{ Lake } & Position & $\begin{array}{c}\text { No. of fish } \\
\text { sampled }\end{array}$ & \multicolumn{2}{c|}{$\begin{array}{c}\text { Host length }(\mathrm{cm}) \\
\text { Range }\end{array}$} & $\begin{array}{c}\text { Prevalence } \\
(\%)\end{array}$ & $\begin{array}{c}\text { Mean } \\
\text { intensity }\end{array}$ & $\begin{array}{c}\text { Mean } \\
\text { abundance }\end{array}$ \\
\hline Aluminé & $38^{\circ} 55^{\prime} \mathrm{S}, 71^{\circ} 10^{\prime} \mathrm{W}$ & 21 & $3.8-6.2$ & $4.8(0.6)$ & 4.8 & 3 & 0.14 \\
Traful & $40^{\circ} 37^{\prime} \mathrm{S}, 71^{\circ} 25^{\prime} \mathrm{W}$ & 6 & $37.5-44$ & $41.5(2.4)$ & 16.7 & 2 & 0.33 \\
Escondido & $41^{\circ} 05^{\prime} \mathrm{S}, 71^{\circ} 35^{\prime} \mathrm{W}$ & 153 & $12.5-41$ & $23.8(6.1)$ & 1.3 & 5 & 0.06 \\
Moreno & $41^{\circ} 06^{\prime} \mathrm{S}, 71^{\circ} 32^{\prime} \mathrm{W}$ & 314 & $15.4-50.7$ & $35.8(7.7)$ & 2.2 & 8 & 0.18 \\
Epuyén & $42^{\circ} 11^{\prime} \mathrm{S}, 71^{\circ} 31^{\prime} \mathrm{W}$ & 32 & $4.6-8.0$ & $5.5(0.7)$ & 6.3 & 5 & 0.31 \\
Rivadavia & $42^{\circ} 36^{\prime} \mathrm{S}, 71^{\circ} 30^{\prime} \mathrm{W}$ & 3 & $26-38$ & $31.6(6.4)$ & 33.0 & 3 & 0.01 \\
\hline
\end{tabular}

\section{DISCUSSION}

Posterotestes unelen is distinguished from previously described species of Apocreadiinae by the presence of tegumental spines, similar size of suckers, prepharynx longer than pharynx, long oesophagus, caeca terminating at the level of the anterior testis, location of gonads at the posterior end of body, extension of vitelline follicles from intestinal bifurcation to the anterior testis and extension of the seminal vesicle to $2 / 3$ of the distance between ventral sucker and ovary.
Prevalence, mean intensity and mean abundance were generally low irrespective of the lake, sampling period and fish size.

Acknowledgements. Funds were provided by UNC Grant (B 092) and PICT FONCYT Grant (01-00002-00067) to L. Semenas and CONICET Grant (BID 1201/OC-AR-PICT no. 1-6604) to M. Ostrowski de Núñez.

\section{REFERENCES}

ARRATIA G. 1982: A review of freshwater percoids from South America. Abh. Senckenb. Naturforsch. Ges. 540: 152.

BRAY R.A., de CHAMBRIER A., VAUCHER C. 1996: Crassicutis intermedius (Szidat, 1954) n. comb. and Procaudotestis uruguayensis Szidat, 1954 (Digenea: Homalometridae) from siluriform fishes in Paraguay. Syst. Parasitol. 35: 119-126.

BUSH A.O., LAFFERTY K., LOTZ M., SHOSTAK A.W. 1997: Parasitology meets ecology on its own terms: Margolis et al. revisited. J. Parasitol. 83: 575-583.

CRIBB T.H., BRAY R. 1999: A review of the Apocreadiidae Skrjabin, 1942 (Trematoda: Digenea) and description of Australian species. Syst. Parasitol. 44: 1-36.

MACCHI P.J., CUSSAC V.E., ALONSO M.F., DENEGRI M.A. 1999: Predation relationships between introduced salmonids and the native fish fauna in lakes and reservoirs in Northern Patagonia. Ecol. Freshwater Fish 8: 227-236.

NELSON J. 1994: Fishes of the World. Third Edition. John Wiley \& Sons, New York, 600 pp.

ORTUBAY S.G., SEMENAS L.G., ÚBEDA C.A., QUAGGIOTTO A.E., VIOZZI G.P. 1994: Catálogo de Peces Dulceacuícolas de la Patagonia Argentina y sus Parásitos Metazoos. Dirección de Pesca, Río Negro, Argentina, $110 \mathrm{pp}$.

OSTROWSKI de NÚÑEZ M., SEMENAS L., BRUGNI N., VIOZZI G., FLORES V. 1999: Redescription of Acanthostomoides apophalliformis (Trematoda, Acanthostomidae) from Percichthys trucha (Pisces, Percichthyidae) with notes on its life cycle in Patagonia, Argentina. Acta Parasitol. 44: 222-228.
OSTROWSKI de NÚÑEZ M., BRUGNI N., VIOZZI G.P. 2000: Polylekithum percai n. sp. (Trematoda: Allocreadiidae) from Percichthys trucha (Perciformes) in Patagonia, Argentina and a redescription of Homalometron papilliferum (Szidat, 1956) n. comb. Syst. Parasitol. 47: 51-57.

SHIMAZU T., URAWA S., CORIA C. 2000: Four species of digeneans, including Allocreadium patagonicum sp. n. (Allocreadiidae), from freshwater fishes of Patagonia, Argentina. Folia Parasitol. 47: 111-117.

SZIDAT L. 1954: Trematodes nuevos de peces de agua dulce de la República Argentina y un intento para aclarar su carácter marino. Rev. Inst. Nac. Invest. Cienc., Nat. Mus. Arg. Cienc. Nat. "Bernardino Rivadavia" B. Aires, Cienc. Zool. 3: 1-85.

SZIDAT L. 1956: Über die Parasitenfauna von Percichthys trucha (Cuv. \& Val.) Girard der patagonischen Gewässer und die Beziehungen des Wirtsfisches und seiner Parasiten zur paläarktischen Region. Arch. Hydrobiol. 51: 542-577.

TORRES P., CONTRERAS A., CUBILlOS V., GESCHE W., MONTEFUSCO A., REBOLLEDO C., MIRA A., ARENAS J., MIRANDA J.C., ASENJO S., SCHLATTER R. 1992: Parasitismo en peces, aves piscívoras y comunidades humanas ribereñas de los lagos Yelcho y TaguaTagua, X Región de Chile. Arch. Méd. Vet. 24: 77-92.

VIOZZI G.P., FLORES V.R., OSTROWSKI de NÚÑEZ M. 1999: Steganoderma szidati n. sp. (Trematoda: Zoogonidae) from Galaxias maculatus (Jenyns) and G. platei Steindachner in Patagonia, Argentina. Syst. Parasitol. 46: 203-208. 